\title{
Analisis Komparatif Peternak Penggemukan Sapi Mitra dan Non Mitra Pada PT. Great Gaint Lifestock dan Kelompok Limousin
}

\section{Comparative Analysis of Partner And Non-Partner Cattle Feedlot In Great Giant Lifestock Company and Limousin Farmer Group}

\author{
Zulkarnain $^{1 *}$, Djoko Umar Said ${ }^{1}$, Novita Dewi ${ }^{1}$, Wintari Mandala ${ }^{2}$ \\ ${ }^{1}$ Sekolah Tinggi Ilmu Pertanian (STIPER) Dharma Wacana, Kota Metro, Indonesia \\ ${ }^{2}$ Universitas Nahdlatul Ulama Lampung \\ ${ }^{1}$ E-mail : zulfadhilalzabir@gmail.com
}

\begin{abstract}
Animal husbandry plays a strategic role in the development of the agricultural sector which aims to meet the needs of animal protein, empower the economic community, and to trigger regional development. Therefore, it is necessary to increase productivity which has an impact on increasing income. Income is used to assess the success of a business and determine the success of a farming business. The objective of this study was to determine the income differences between partner cattle farmers and non-partner cattle farmers. The research method was a survey method carried out in Astomulyo Village, Punggur District, Central Lampung Regency. The samples of this research were 54 partner farmers and 10 non-partner farmers. The analysis methods used were income analysis, $R / C$ ratio and t test analysis. The results showed that the total income of partner farmers was Rp.28,490,166.67. It was Rp12,755,066.7 lower than non-partner farmers which was Rp.41,245,233.33. From the income analysis, it was found that the ratio of farmer income to the total cost of nonpartner farmers was 1.26 and partner farmers with a value of 1.15. Statistically, there is no significant difference between the selling price of partner and non-partner cattle farmers.
\end{abstract}

Keywords: Partnership, Comparative, Income, Farmer, Rearing, Cattle

Disubmit : 10 Februari 2020, Diterima: 7 Maret 2020, Disetujui :28 April 2020

\section{PENDAHULUAN}

Agribisnis berbasis peternakan adalah salah satu fenomena yang tumbuh pesat ketika ketersediaan lahan menjadi terbatas, karena sistem usahatani memerlukan lahan yang besar namun ketersediaan lahan yang terbatas akan memicu efisiensi dan efektifitas penggunaan lahan tersebut. Oleh karena itu usaha peternakan dapat dijadikan salah satu alternatif yang menjanjikan nilai keuntungan dimasa depan (Arifin, 2004). Pembangunan peternakan merupakan bagian integral dari pembangunan diversifikasi pangan, perbaikan mutu gizi masyarakat dan mengembangkan ekspor (Rahmah, 2018). Sub sektor peternakan memiliki peran yang strategis dalam pembangunan sektor pertanian yaitu dalam upaya pemantapan ketahanan pangan untuk memenuhi kebutuhan protein hewani, pemberdayaan ekonomi masyarakat, dan dapat memacu pengembangan wilayah (Daryanto, 2011).

Usaha pada peternakan sapi berupa usaha penggemukan sapi. Usaha penggemukan sapi sangat berbeda dengan usaha pembiakan (Tawaf, 2018). Usaha pengemukan sapi secara komersial dapat dilakukan oleh peternak yang memiliki modal besar dan menerapkan teknologi modern (Mubyarto dalam Anggraini, 2003). Integrasi ternak dapat dilakukan melalui pola kemitraan antara pihak perusahaan dan petani-ternak 
(Suharto, 2004). Mengelola sektor peternakan secara profesional menjadi kewajiban pemerintah dalam upaya mendongkrak tingkat kesejahteraan rakyatnya (Jamilah, 2017). Usaha peternakan sapi juga dapat mendorong program swasembada daging sapi yang dilakukan oleh pemerintah(Suardi dkk, 2018).

Sentral produksi ternak sapi di Provinsi Lampung adalah Kabupaten Lampung Tengah (Badan Pusat Statistik, 2016). Di Kabupaten Lampung Tengah selalu mengalami kenaikan dari tahun ke tahun(Badan Pusat Statistik, 2016). Usaha ternak sapi di Kabupaten Lampung Tengah khususnya di Kecamatan Punggur sebagian besar masih merupakan usaha peternakan rakyat dalam skala kecil. Upaya pengembangan usaha peternakan sapi di Kecamatan Punggur peternak sapi melakukan kemitraan dengan PT. Great Giant Lifestock Lampung Tengah. Mengingat peternakan sapi potong termasuk usaha dengan penanaman modal yang tinggi per tenaga kerjanya, bila dibandingkan dengan kebanyakan usaha lain. Hal ini menuntut penggunaan yang maksimum ingin dicapai, dengan produksi daging sapi tahunan yang tinggi merupakan hasil dari perhatian yang dicurahkan setiap hari terhadap segala hal yang berhubungan dengan breeding, feeding dan management.

Selain modal yang diperlukan sangat besar, kegiatan pemasaran sapi potong juga belum banyak diatur oleh Pemerintah, dimana usaha pemasaran lebih banyak diatur oleh lembaga pemasaran yang berskala besar seperti perusahaan sapi atau feedlot dan pedagang pengumpul (Yusdja $d k k$., 2003). Upaya peningkatan daya saing usaha ternak sapi potong secara teknis dapat dilakukan dengan kemitraan (Kuswaryan $d k k$., 2004). Dengan berpartisipasi kemitraan dapat meningkatkan produktivitas, karena petani mendapat bimbigan teknis, informasi, dan jaminan pasar (Fitri $d k k$, 2018). Sapi potong merupakan kelompok ruminansia penyumbang produksi daging terbesar nasional, sehingga usaha ternak berpotensi untuk dikembangkan sebagai usaha yang menguntungkan (Satiti $d k k$, 2017). Usaha ternak sapi di Kabupaten Lampung Tengah khususnya di Kecamatan Punggur sebagian besar masih merupakan usaha peternakan rakyat dalam skala kecil. Upaya dalam pengembangan usaha peternakan sapi di Kecamatan Punggur peternak sapi dilakukan kemitraan dengan PT. Great Giant Lifestock Lampung Tengah. Berdasarkan uraian, maka tujuan penelitian yaitu untuk mengetahui perbedaan pendapatan peternak sapi mitra dengan peternak sapi non mitra

\section{METODE PENELITIAN}

Waktu dan Tempat Penelitian. Penelitian ini dilaksanakan pada bulan Oktober 2019 di Kampung Astomulyo Kecamatan Punggur Kabupaten Lampung Tengah. Dengan pertimbangan bahwa di Provinsi Lampung yang memiliki tingkat populasi ternak sapi tertinggi dari tahun 2014 - 2016 yaitu pada tahun 2014 sebanyak 205.986 ekor, tahun 2015 sebanyak 260.054 ekor dan tahun 2016 sebanyak 206.569 ekor. Dapat di simpulkan bahwa pada setiap tahunnya di Kabupaten Lampung Tengah mengalami kenaikan jumlah populasi ternak sapi.

Metode Pengumpulan Data. Data yang diambil untuk penelitian adalah data primer dan data sekunder, baik bersifat kuantitatif maupun kualitatif. Data primer diperoleh dari pengamatan langsung dan wawancara langsung dengan petani responden berdasarkan kuisioner yang telah disusun sesuai dengan tujuan penelitian. Data sekunder diperoleh dari buku yang dibaca, berbagai pustaka dan instansi-instansi terkait lainnya yang dapat melengkapi data yang diperlukan untuk penelitian.

Populasi dan Sampel. Populasi dalam penelitian ini adalah peternak yang bermitra dengan PT.GGL

di Kelompok Limousin Kampung Astomulyo. Berdasarkan hasil wawancara dengan ketua Kelompok Limousin di Kampung Astomulyo di ketahui bahwa peternak sapi potong yang bermitra dengan PT.GGL adalah sebanyak 64 peternak, 54 peternak mitra dan 10 peternak non mitra, dengan jumlah sampel yang digunakan dalam penelitian ini berjumlah 54 sampel untuk peternak mitra dan 10 sampel untuk peternak non mitra. 
Analisis Usahatani. Pindyck dan Rubinfield (2001); Soekartawi (2002); dan Soekartawi (2006) merumuskan secara matematis untuk menghitung pendapatan adalah sebagai berikut :

Keterangan:

$$
\pi=\mathrm{TR}-\mathrm{TC}
$$

$$
\begin{array}{ll}
\pi=\text { Pendapatan usahatani } & (\mathrm{Rp} .) \\
\mathrm{TR}=\text { Total penerimaan } & (\mathrm{Rp} .) \\
\mathrm{TC}=\text { Total biaya } & (\mathrm{Rp} .)
\end{array}
$$

Analisis R/C Ratio. Menurut Soekartawi (2002) tingkat pendapatan usahatani diukur dengan analisis penerimaan dan biaya ( $R / C$ Ratio) yang artinya besarnya penerimaan usahatani yang akan diperoleh produsen untuk setiap rupiah biaya yang dikeluarkan pada usahatani.

$$
\text { Rasio } \mathrm{R} / \mathrm{C}=\underline{\mathrm{TR}}
$$

$$
\mathrm{TC}
$$

Keterangan :

$\mathrm{R} / \mathrm{C}=$ Nisbah penerimaan dan biaya

$\mathrm{TR}=$ Total revenue atau penerimaan total (Rp.)

TC $=$ Total cost atau biaya total (Rp.)

Uji Statistik dengan Uji-t. Menurut Ghozali (2012) Uji beda t test digunakan untuk menguji seberapa jauh pengaruh variabel independen yang digunakan dalam penelitian ini secara individual dalam menerangkan variabel dependen secara parsial. Dasar pengambilan keputusan digunakan dalam uji-t adalah sebagai berikut :

Ho : $\pi_{\mathrm{m}}=\pi_{\mathrm{nm}}$

Pendapatan usahatani peternak mitra sama dengan pendapatan usahatani peternak non mitra.

$>\mathrm{Ha}: \pi_{\mathrm{m}}>\pi_{\mathrm{nm}}$

Pendapatan usahatani peternak mitra lebih tinggi dari pada pendapatan usahatani peternak non mitra.

\section{HASIL DAN PEMBAHASAN}

Konsep kemitraan yang dijalankan oleh PT. Geat Giant Lifestock dan Peternak Sapi di Kampung Astomulyo digolongkan ke dalam pola Kerjasama Operasional Agribisnis (KOA). Konsep tersebut tercantum dalam perjanjian kerjasama antara perusahaan dengan peternak, dimana kedua perusahaan mempunyai peranan yang sama yaitu menyediakan sarana produksi untuk peternak yang bermitra. Kerjasama perusahaan dengan peternak meliputi:

1. Perusahaan selaku pihak pertama adalah produsen yang menyediakan sapronak kepada peternak mitra.

2. Sapronak yang diperoleh dari perusahaan selanjutnya dikembangkan dan dibudidayakan oleh peternak mitra selaku pihak kedua.

3. Peternak mitra haruslah peternak yang mempunyai pengetahuan dan keterampilan dalam mengelola usaha budidaya ternak sapi dan memiliki atau mampu menyewa lahan serta kandang sapi dan mampu menggaji tenaga kerja yang dapat digunakan untuk pembudidayaan sapi.

4. Perusahaan membantu peternak dalam memasarkan hasil panen.

Analisis pendapatan usahatani peternak sapi mitra di daerah penelitian sebagai berikut. 
Tabel 1. Perhitungan Pendapatan Usahatani Peternak Sapi Mitra

\begin{tabular}{|c|c|c|c|c|}
\hline \multirow{2}{*}{ Uraian } & \multirow{2}{*}{ Satuan } & \multicolumn{3}{|c|}{ Mitra } \\
\hline & & Jumlah & Harga (Rp.) & Nilai (Rp.) \\
\hline \multicolumn{5}{|l|}{ Produksi } \\
\hline - Kotoran Sapi & Karung & 52,84 & $12.000,00$ & $634.042,55$ \\
\hline - Berat Sapi & $\mathrm{Kg}$ & 553,01 & $42.500,00$ & $23.503 .102,84$ \\
\hline Penerimaan & $\mathrm{Rp}$ & & & $24.137 .145,39$ \\
\hline \multicolumn{5}{|l|}{ Biaya Produksi } \\
\hline \multicolumn{5}{|l|}{ a. Biaya variabel } \\
\hline $\begin{array}{ll}\text { - } & \text { Bibit } \\
\text { - } & \text { Pakan }\end{array}$ & $\mathrm{Kg}$ & & & 16.106.382,98 \\
\hline - Kulit Nanas & $\mathrm{Kg}$ & $1.119,15$ & 285,00 & $318.957,45$ \\
\hline - Kulit Singkong & $\mathrm{Kg}$ & $1.119,15$ & 250,00 & $279.787,23$ \\
\hline - Konsentrat & $\mathrm{Kg}$ & 600,00 & $2.300,00$ & $1.380 .000,00$ \\
\hline - Obat Cacing & & & & $8.085,11$ \\
\hline - Antibiotik & & & & $10.106,38$ \\
\hline - Vitamin & & & & $14.148,94$ \\
\hline - Tenaga Kerja Luar Keluarga & & & & $801.272,73$ \\
\hline - Tenaga Kerja Dalam & & & & $766.451,61$ \\
\hline \multicolumn{5}{|l|}{ Keluarga } \\
\hline Total Biaya Variabel & $\mathrm{Rp}$ & & & $19.685 .192,43$ \\
\hline \multicolumn{5}{|l|}{ b. Biaya di Tetap } \\
\hline • Investasi & & & & $1.033 .758,87$ \\
\hline - Penyusutan Alat & & & & $39.219,86$ \\
\hline - Penyusutan Kandang & & & & $186.660,38$ \\
\hline Total Biaya di Tetap & $\mathrm{Rp}$ & & & $1.259 .639,10$ \\
\hline Total Biaya & $\mathrm{Rp}$ & & & $20.944 .831,53$ \\
\hline \multicolumn{5}{|l|}{ Pendapatan } \\
\hline Pendapatan atas biaya Variabel & $\mathrm{Rp}$ & & & $4.451 .952,96$ \\
\hline Pendapatan atas biaya Total & $\mathrm{Rp}$ & & & $3.192 .313,86$ \\
\hline \multicolumn{5}{|l|}{ R/C Ratio } \\
\hline $\mathrm{R} / \mathrm{C}$ ratio atas biaya Variabel & & & & 1,23 \\
\hline $\mathrm{R} / \mathrm{C}$ ratio atas biaya Total & & & & 1,15 \\
\hline
\end{tabular}

Sumber : Data Primer diolah 2019

Berdasarkan Tabel 1 menunjukkan bahwa penerimaan yang diperoleh berasal dari hasil penjualan kotoran sapi dan berat sapi dari peternak sapi mitra. Kotoran sapi per satu ekor rata rata yang dihasilkan sebanyak 52,84 karung per satu kali masa panen dengan harga yang berlaku yaitu Rp 12.000,00/karung, sehingga jumlah penerimaan yang di dapat sebesar Rp 634.042,55 per masa panen, sedangkan untuk penerimaan dari penjualan sapi berat satu sapi rata - rata seberat 553,01 kg dengan harga yang berlaku dari mitra sebesar Rp 42.500/kg sehingga di dapat penerimaan dari hasil penjualan sapi sebesar Rp 23.503.102,84 per masa panen.

Jumlah biaya yang dikeluarkan dari biaya variable terdiri dari biaya bibit satu ekor sapi rata - rata sebesar Rp 16.106.382,98. Pemberian pakan dan konsentrat untuk satu sapi/hari menghabiskan $10 \mathrm{~kg}$ kulit 
nanas, $10 \mathrm{~kg}$ kulit singkong dan $5 \mathrm{~kg}$ konsentrat, sedangkan untuk biaya dalam satu masa panen petenak untuk satu ekor sapi biasa menghabiskan kulit nanas rata - rata sebanyak 1.119,15 kg dengan harga yang berlaku sebesar Rp 285,00/kg sehingga biaya pakan kulit nanas sebesar Rp 318.957,45 sedangkan untuk pakan kulit singkong menghabiskan 1.119,15 kg dengan harga yang berlaku Rp 250/kg sehingga jumlah biaya pakan kulit singkong sebesar Rp 279.787,23 per satu masa panen, untuk biaya konsentrat peternak menghabiskan $600 \mathrm{~kg}$ per masa panen dengan harga yang berlaku Rp 2.300/kg, jumlah biaya konsentrat Rp 1.380.000,00 per masa panen.

Untuk biaya obat dan vitamin petenak menggunakan obat cacing rata - rata untuk satu ekor sapi sebanyak 0,20 botol sebesar Rp 8.085,11 dan antibiotik sebanyak 0,20 botol sebesar Rp 10.106,00 untuk vitamin menggunakan jenis injektamin sebanyak 0,20 botol biaya yang dikeluarkan sebesar Rp 14.148,94, dan yang termasuk biaya variabel selanjutnya yaitu biaya tenaga kerja luar keluarga yang dimana hanya beberapa yang menggunakan tenaga kerja luar keluarga dengan biaya untuk sapi ekor sapi sebesar Rp 801.272,73 sedangkkan banyak dari beberapa peternak yang menggunakan tenaga kerja dalam keluarga dengan biaya untuk sapi ekor sapinya sebesar $\mathrm{Rp} 766.451,61$. Selain biaya variable, terdapat biaya tetap yang berupa biaya investasi kandang sabesar Rp. 1.033.758,87 dan biaya penyusutan alat rata - rata untuk seluruh pnggunaan alat per sapi ekor sapinya sebesar Rp 39.219,86 per masa panen, adapun biaya penyusutan kandang sebesar Rp 186.660,38. Dari perhitungan biaya variabel dan biaya tetap didapat biaya total yang dikeluarkan untuk biaya satu ekor sapi sebesar Rp 20.944.831,53 per masa panen. Berdasarkan perhitungan penerimaan dan biaya total yang diluarkan maka didapat pendapatan peternak yang dimana diperoleh dari penerimaan dikurang dengan biaya total, dimana pendapatan peternak yang didapat untuk satu ekor sapi sebesar Rp 3.192.313,86. Analisis pendapatan telah dilakukan, diperolah bahwa ratio penerimaan peternak terhadap biaya total peternak mitra dengan nilai sebesar 1,15 , dimana ratio ini dapat diartikan setiap $\mathrm{Rp}$ 1.000 biaya total yang dikeluarkan akan memperoleh penerimaan sebesar Rp 1.150,00. Pendapatan usahatani peternak sapi non-Mitra sebagai berikut.

Tabel 2. Perhitungan Pendapatan Usahatani Peternak Sapi Non Mitra

\begin{tabular}{|c|c|c|c|c|}
\hline \multirow{2}{*}{ Uraian } & \multirow{2}{*}{ Satuan } & \multicolumn{3}{|c|}{ Non Mitra } \\
\hline & & Jumlah & Harga (Rp.) & Nilai (Rp.) \\
\hline \multicolumn{5}{|l|}{ Produksi } \\
\hline • Kotoran Sapi & karung & 47,37 & $12.000,00$ & $568.421,05$ \\
\hline - Berat Sapi & $\mathrm{Kg}$ & 618,25 & $43.000,00$ & $26.584 .561,40$ \\
\hline Penerimaan & $\mathrm{Rp}$ & & & $27.152 .982,46$ \\
\hline \multicolumn{5}{|l|}{ Biaya Produksi } \\
\hline \multicolumn{5}{|l|}{ a. Biaya Variabel } \\
\hline $\begin{array}{l}\text { - Bibit } \\
\text { - Pakan }\end{array}$ & $\mathrm{Kg}$ & & $16.000 .000,00$ & $16.000 .000,00$ \\
\hline - Kulit Nanas & $\mathrm{Kg}$ & $1.350,00$ & 280,00 & $378.000,00$ \\
\hline - Kulit Singkong & $\mathrm{Kg}$ & $1.350,00$ & 250,00 & $337.500,00$ \\
\hline - Konsentrat & $\mathrm{Kg}$ & 900,00 & $2.300,00$ & $2.070 .000,00$ \\
\hline - Obat Cacing & & & & $8.421,05$ \\
\hline - Antibiotik & & & & $9.649,12$ \\
\hline - Vitamin & & & & $15.964,91$ \\
\hline - Tenaga Kerja Dalam keluarga & $\mathrm{Rp}$ & & & $1.176 .923,07$ \\
\hline Total Biaya Variabel & $\mathrm{Rp}$ & & & $19.996 .458,16$ \\
\hline
\end{tabular}




\begin{tabular}{|c|c|c|c|c|}
\hline \multirow{2}{*}{ Uraian } & \multirow{2}{*}{ Satuan } & \multicolumn{3}{|c|}{ Non Mitra } \\
\hline & & Jumlah & Harga (Rp.) & Nilai (Rp.) \\
\hline \multicolumn{5}{|l|}{ b. Biaya Tetap } \\
\hline - Investasi & & & & $1.188 .596,49$ \\
\hline - Penyusutan Alat & & & & $35.336,25$ \\
\hline - Penyusutan kandang & & & & $320.478,28$ \\
\hline Total Biaya Tetap & & & & $1.544 .411,03$ \\
\hline Total Biaya & $\mathrm{Rp}$ & & & $21.540 .869,19$ \\
\hline \multicolumn{5}{|l|}{ Pendapatan } \\
\hline Pendapatan atas biaya Variabel & $\mathrm{Rp}$ & & & $7.156 .524,29$ \\
\hline Pendapatan atas biaya Total & $\mathrm{Rp}$ & & & $5.612 .113,26$ \\
\hline \multicolumn{5}{|l|}{ R/C Ratio } \\
\hline $\mathrm{R} / \mathrm{C}$ ratio atas biaya Variabel & & & & 1,36 \\
\hline $\mathrm{R} / \mathrm{C}$ ratio atas biaya Total & & & & 1,26 \\
\hline
\end{tabular}

Sumber : Data Primer diolah 2019

Berdasarkan Tabel 2 menunjukkan bahwa penerimaan yang diterima berasal dari hasil penjualan kotoran sapi dan hasil penjualan berat sapi dari peternak sapi non mitra. Kotoran per satu ekor rata - rata yang dihasilkan sebanyak 47.37 karung per satu kali masa panen dengan harga yang berlaku yaitu $\mathrm{Rp}$ 12.000,00/karung, dengan jumlah penerimaan yang didapat sebesar Rp 568.421,05 per masa panen, sedangkan untuk penerimaan dari penjualan sapi berat satu sapi rata - rata seberat 618,25 kg dengan harga yang berlaku dari mitra sebesar Rp 43.000,00/kg sehingga didapat penerimaan dari hasil penjualan sapi sebesar Rp 26.584.561,14 per masa panen.

Jumlah biaya yang dikeluarkan dari biaya variabel terdiri dari biaya bibit satu ekor sapi rata - rata sebesar Rp 16.000.000,00. Pemberian pakan dan konsentrat untuk satu sapi/hari menghabiskan 7,5 kg kulit nanas, 7,5 kg kulit singkong dan $5 \mathrm{~kg}$ konsentrat, sedangkan untuk biaya dalam satu masa panen petenak untuk satu ekor sapi biasa menghabiskan kulit nanas rata - rata sebanyak $1.350 \mathrm{~kg}$ dengan harga yang berlaku sebesar Rp 280/kg sehingga biaya pakan kulit nanas sebesar Rp 378.000,00 sedangkan untuk pakan kulit singkong menghabiskan $1.350 \mathrm{~kg}$ dengan harga yang berlaku Rp 250/kg sehingga jumlah biaya pakan kulit singkong sebesar Rp 337.500,00 per satu masa panen, untuk biaya konsentrat peternak menghabiskan $900 \mathrm{~kg}$ per masa panen dengan harga yang berlaku Rp 2.300/kg, jumlah biaya konsentrat Rp 2.070.000,00 permasa panen.

Untuk biaya obat dan vitamin petenak menggunakan obat cacing rata - rata untuk satu ekor sapi sebanyak 0,21 botol sebesar Rp 8.421,05 dan antibiotik sebanyak 0,19 botol sebesar Rp 9.649,12, untuk vitamin menggunakan jenis injektamin sebanyak 0,23 botol biaya yang dikeluarkan sebesar Rp 15.964,91, dan yang termasuk biaya variabel selanjutnya yaitu biaya tenaga kerja dalam keluarga dimana seluruh peternak menggunakan tenaga kerja dalam keluarga dengan biaya untuk sapi ekor sapinya sebesar Rp 1.176.923,08. Selain biaya variable, terdapat biaya tetap yang berupa biaya investasi kandang sebesar Rp. 1.188.596,49 dan biaya penyusutan alat rata - rata untuk seluruh pnggunaan alat per sapi ekor sapinya sebesar Rp 35.386,26 per masa panen, adapun biaya penyusutan kandang sebesar Rp 320.478,28. Dari perhitungan biaya variabel dan biaya tetap didapat biaya total yang dikeluarkan untuk biaya satu ekor sapi sebesar Rp 21.546.869,19 per masa panen. Berdasarkan perhitungan penerimaan dan biaya total yang diluarkan maka didapat pendapatan peternak yang dimana diperoleh dari penerimaan dikurang dengan biaya total, dimana pendapatan peternak yang didapat untuk satu ekor sapi sebesar Rp 5.612.113,26. Analisis 
pendapatan telah dilakukan, diperolah bahwa ratio penerimaan peternak terhadap biaya total peternak non mitra dengan nilai sebesar 1,26, dimana ratio ini dapat diartikan setiap Rp 1.000,00 biaya total yang dikeluarkan akan memperoleh penerimaan sebesar Rp 1.260,00.

Perhitungan rasio penerimaan atas biaya total menunjukan lebih besar dari pada satu $(\mathrm{R} / \mathrm{C}>1)$, ini berarti bahwa usahatani yang dilakukan oleh petani menguntungkan dimana penerimaan yang diperoleh lebih besar dari pada biaya yang dikeluarkan. Hal ini berarti peternak sapi mitra dan peternak sapi non mitra sama - sama menguntungkan jika di lihat dari (R/C Rationya). Dengan adanya kemitraan maka peternak dapat dengan mudah memaksimalkan penggunaan sarana produksi, dimana peternak susah mendapat sarana produksi yang menjadi kendala bagi petani untuk kelangsungan usahatani.

Uji Beda Peternak Mitra dan Paternak Non Mitra. Uji beda pada penelitian ini menggunakan teknik statistik Independent-Sample T-Test dengan bantuan SPSS. Hasil uji perbedaan data penelitian ditampilkan pada tabel 3.

Tabel 3. Uji Beda Pendapatan Sapi Mitra dan Sapi Non Mitra

\begin{tabular}{ccccc}
\hline Sapi Mitra & Sapi Non Mitra & $\mathbf{t}_{\text {Hitung }}$ & Probability & Kesimpulan \\
\hline $28.490 .166,67$ & $41.245 .233,33$ & 2.047 & 0,045 & Ha diterima, dan Ho ditolak \\
\hline
\end{tabular}

Sumber : Data Primer diolah 2019

Berdasarkan Tabel 3 menunjukkan bahwa secara setatistik ada perbedaan yang tidak signifikan antara harga jual sapi mitra dan sapi non mitra di Kampung Astomulyo. Rata - rata pendapatan usahatani sapi mitra perpanen adalah sebesar Rp. 28.490.166,67 sedangkan pendapatan sapi non mitra adalah sebanyak Rp. 41.245.233,33 secara statistik terlihat bahwa pendapatan usahatani sapi non mitra lebih besar ketimbang usahatani sapi mitra, dengan hasil uji beda (t-hitung ) sebesar 2.047 dan berbeda secara nyata dengan probabilitas sebesar 0,045 lebih dari 0,05 maka Ha diterima, artinya bahwa adanya perbedaan yang signifikan menggunakan sapi mitra dan sapi non mitra. Menurut Tawaf (2010) mengutarakan bahwa usaha penggemukan sapi potong yang dilaksanakan oleh peternakan rakyat memiliki keunggulan komparatif, sehingga secara finansial menguntungkan. yang bermitra. Hal ini sejalan dengan penelitian Suryana dalam Roessali (2005) mengatakan bahwa usaha tani atau usaha ternak sapi potong rakyat umumnya berskala kecil bahkan subsisten. Selain itu, harga daging impor yang lebih murah dibandingkan dengan harga daging sapi lokal, sehingga sapi impor menjadi pesaing berat bagi para peternak daging sapi lokal(Suardi $d k k, 2018$ ).

Hal ini terjadi karena pengeluaran oprasional dari sapi mitra lebih tinggi, dari segi perawatannya juga memerlukan dana yang sangat besar untuk pembelian pakan yang membuat perbedaan yang signifikan pendapatan usahatani sapi mitra dan usahatani sapi non mitra, akan tetapi untuk masa panen lebih lama untuk usahatani sapi non mitra yang sampai 4-7 bulan/panen sesuai keinginan peternak, sedangkan masa panen sapi mitra hanya sampai 4-5 bulan/panen sesuai dengan kondisi sapi yang sudah memungkinkan untuk dipanen. Sejalan dengan penelitian Deshinta (2006) dari hasil uji terhadap pendapatan total ternyata kemitraan tidak berpengaruh terhadap peningkatan pendapatan peternak. Walaupun demikian, peternak memperoleh banyak manfaat dari keikutsertaannya di dalam kemitraan seperti pinjaman sapronak, menambah ilmu pengetahuan,pemasaran hasil panen,dan pelaksanaan control dari perusahaan .

\section{KESIMPULAN}

Jumlah pendapatan peternak mitra sebesar Rp 28.490.166,67 lebih redah Rp12.755.066.7 dari pada peternak non mitra sebesar Rp 41.245.233,33 karena peternak mitra menanggung biaya yang lebih besar dari peternak non mitra, dan harga jual lebih rendah sapi mitra dari sapi non mitra. Dari hasil uji terhadap pendapatan total ternyata kemitraan tidak berpengaruh terhadap peningkatan pendapatan peternak. Walaupun demikian, peternak memperoleh banyak manfaat dari keikutsertaannya didalam kemitraan seperti pinjaman sapronak, menambah ilmu pengetahuan, pemasaran hasil panen, dan pelaksanaan kontrol dari perusahaan. 


\section{DAFTAR PUSTAKA}

Anggraini, W. (2003) Analisis Usaha Peternakan Sapi Potong Rakyat Berdasarkan Biaya Produksi dan Tingkat Pendapatan Peternakan Menurut Skala Usaha. Institut Pertanian Bogor.

Arif Daryanto (2011) ‘Peranan Modal Sosial dalam Pembangunan Peternakan’, Trobos.

Arifin, B. (2004) Analisis Ekonomi Pertanian Indonesia. Jakarta: Kompas.

Badan Pusat Statistik (2016) Statistik Lampung. Lampung. Indonesia. Produk Domestik Regional Bruto (PDRB). Lampung.

Deshinta, M. (2006) Peranan kemitraan terhadap peningkatan pendapatan peternak ayam broiler. INSTITUT PERTANIAN BOGOR.

Fitri, A., Harianto, H. and Asmarantaka, R. W. (2018) 'The Effects of Partnerships on the Efficiency of Mustard Farming at Megamendung District', Jurnal Manajemen dan Agribisnis, 15(1), pp. 12-22. doi: 10.17358/jma.15.1.12.

Ghozali I (2012) Aplikasi Analisis Multivariate Dengan Program IBM SPSS 20. Semarang: Badan Penerbitan Universitas Diponegoro.

Jamilah (2017) ‘ANALISIS PENDAPATAN PETERNAK SAPI ACEH', AGRIFO, 2(2), pp. 50-55.

Pindyck RS (2001) Microeconomics. Prentice Hall.

Rahmah, U. I. L. (2018) 'Keragaan Usaha Ternak Sapi Perah Anggota dan Non Anggota Non-Members Of Cooperatives di Kecamatan Banjaran', Jurnal Pertanian dan Peternakan, 6(2), pp. 150-160.

Roessali, W.B., Eddfy, T., \& Murthado, A. (2005) 'Usaha Pengembangan Sapi Potong Melalui Intenitas Agribisnis “Corporate Farmin” Di Kabupaten Grobongan', Jurnal Sosial Ekonomi Peternakan, 1(1), pp. 25-30.

Satiti, R., Lestari, D. A. H. and Suryani, A. (2017) 'Sistem Agribisnis dan Kemitraan Usaha Penggemukan Sapi Potong di Koperasi Gunung Madu’, Jurnal Ilmu-Ilmu Agribisnis, 5(4), pp. 352-359.

Soekartawi (2002) Prinsip Dasar Ekonomi Pertanian. Jakarta: Raja Grafindo Persada.

Soekartawi (2006) Analisis Usaha Tani. Jakarta: UI Press.

Suardi, A. N., Cahyadi, E. R. and Basith, A. (2018) 'Model Bisnis Kanvas Pada Sekolah Peternakan Rakyat ( Spr ) Di Kabupaten Muara Enim Business Model Mapping for Sekolah Peternakan Rakyat ( SPR ) at Muara Enim District', Journal of Food System and Agribusiness, 2(2), pp. 67-74.

Suharto (2004) 'Pengalaman pengembangan usaha sistem integrasi sapi-kelapa sawit di Riau', in Prosiding Lokakarya Nasional Sistem Integrasi Kelapa Sawit-Sapi. Bengkulu: . Departemen Pertanian bekerja sama dengan Pemerintah Provinsi Bengkulu dan PT Agricinal, pp. 57-63.

Tawaf, R. (2018) 'Analisis Usaha Pembiakan Sapi Potong Pola Kemitraan Antara Korporasi Dengan Peternak Rakyat', 20(1), pp. 45-56.

Tawaf, R. and S. D. (2010) 'Response of Feedlot Business to The Beef Market Mechnism Changed in West Java Indonesia', Journal Lucrari Stiintifice, 54, pp. 87-93. 